\title{
Swimming behaviour of larvae of the ocean quahog Arctica islandica in response to pressure and temperature*
}

\author{
Roger Mann ${ }^{1}$ and Charlotte C. Wolf ${ }^{2}$ \\ 'Woods Hole Oceanographic Institution, Woods Hole, Massachusetts 02543, USA \\ ${ }^{2}$ Department of Biochemistry, Duke University, Durham, North Carolina, USA
}

\begin{abstract}
Trochophore larvae of the ocean quahog Arctica islandica swim continuously. At a constant temperature of $12{ }^{\circ} \mathrm{C}$ they are negatively geotactic, have no phototactic response and exhibit no change in swimming behaviour in the pressure range 1 to 3 bar. In a vertical thermal gradient from 9 to $25^{\circ} \mathrm{C}$ the trochophores swim throughout the experimental chamber and show no temperature preference. Veliger larvae of $A$. islandica alternate between periods of active upward swimming in vertically oriented helices, that is a negative geotaxis, and periods of passive sinking with the velum either trailing or retracted between closed valves. They do not swim in the horizontal plane and, in the length range 160 to $202 \mu \mathrm{m}$, show no phototactic response. When exposed to sequential increases and decreases in hydrostatic pressure at $12{ }^{\circ} \mathrm{C}$, larvae in the length range 160 to $196 \mu \mathrm{m}$ consistently exhibited a net upward movement following an increase in pressure and a net downward movement following a decrease in pressure. The threshold pressure change to elicit response is $<0.5$ bar. Larvae of $170 \mu \mathrm{m}$ length respond to increased pressure by decreasing the diameter of the helix and increasing the height gain per rotation. Larvae of $196 \mu \mathrm{m}$ length respond to increased pressure by increasing height per rotation and vertical velocity. Larvae of $202 \mu \mathrm{m}$ length exhibit no significant change in swimming behaviour with increased pressure. In a vertical thermal gradient early veligers swim in the range 7 to $23^{\circ} \mathrm{C}$ with preferential aggregation, depending upon size, in the range 12 to $18{ }^{\circ} \mathrm{C}$. Larvae of $204 \mu \mathrm{m}$ length show no temperature preference in the range 6 to $20^{\circ} \mathrm{C}$. The implication of the observed behaviour on seasonal depth distribution of $A$. islandica larvae in the Middle Atlantic Bight is discussed.
\end{abstract}

\section{INTRODUCTION}

Arctica islandica is a member of the Boreal molluscan fauna which occupies a latitudinal range on the eastern coast of North America from Labrador to Cape Hatteras (Franz and Merrill, 1980). In the Middle Atlantic Bight the species is generally limited to a bathymetric range of 25 to $80 \mathrm{~m}$ corresponding to that of the 'Cold Pool' of Bigelow (1933; see also Merrill and Ropes, 1969). South of Cape Cod the spawning season of $A$. islandica extends from June through November with a maximum in late August, September, and early October (Loosanoff, 1953; Jones, 1982; Mann, 1982). This time interval encompasses a transition from thermal stratification in the water column in

\footnotetext{
- Contribution No. 5276 from Woods Hole Oceanographic
} Institution
July, when surface temperature exceeds $20^{\circ} \mathrm{C}$ but bottom $\left(40\right.$ to $50 \mathrm{~m}$ ) temperature is only 9 to $10^{\circ} \mathrm{C}$ (Mann, 1982 ), to a vertically well mixed water column in October. The question arises as to what extent does the presence of a relatively shallow $(\sim 20 \mathrm{~m})$, seasonal thermocline influence the vertical distribution of larvae of $A$. islandica in the Middle Atlantic Bight.

Marine bivalve larvae alternate periods during which they swim upwards in a straight line or in vertically oriented helices (Cragg and Gruffydd, 1975; Cragg, 1980) with periods of passive sinking during which the velum is trailed or the valves are closed. Movement in the horizontal plane is essentially passive. In estuaries, dispersal of bivalve larvae is effected through a combination of active depth regulation and passive horizontal movement (Carriker, 1961; Wood and Hargis, 1971). Bivalve larvae will respond in varying degrees to light (Bayne, 1964), gravity (Bayne, 1964) and pressure (Bayne, 1963; Cragg and Gruffydd, 
1975; Cragg, 1980) stimuli. The deep bathymetric range of Arctica islandica adults in the Middle Atlantic Bight suggests that pressure might strongly influence the swimming behaviour of newly spawned larvae. Similarly the presence of the seasonal thermocline at the time of spawning (Mann, 1982) with surface temperatures in excess of the lethal limit of the larvae (Landers, 1976) suggests that temperature might also influence larval swimming behaviour and depth regulation. This paper describes the results of laboratory experiments to examine the influence of both pressure and temperature stimuli on the swimming behaviour of the larvae of $A$. islandica.

\section{METHODS}

Adult Arctica islandica were collected in July 1981 east of Block Island, Rhode Island, USA, by F.V.'Albert Quito', landed at Point Judith, RI and transported on ice to Woods Hole, MA, where they were maintained in flowing sea water at $15^{\circ} \mathrm{C}$. The time interval during collection and transportation when the bivalves were out of water did not exceed $5 \mathrm{~h}$. Within $1 \mathrm{wk}$ of collection bivalves that exhibited active pumping, fecal production, and no adverse effects from collection and transportation were stripped of their gametes. Fertilization was effected as described by Landers (1976) and Lutz et al. (1982). The trochophore and subsequent shelled larval stages were maintained with gentle aeration in $0.22 \mu \mathrm{m}$ filtered sea water at a density of ca. 10 larvae $\mathrm{ml}^{-1}$ at $12.0^{\circ} \mathrm{C}\left( \pm 0.2 \mathrm{C}^{\circ}\right.$ range $)$ in $50 \mathrm{l}$ polyethylene (Nalgene) containers. The water in the culture container was changed twice per week at which time larvae were fed on a monoculture of Tahitian strain Isochrysis galbana at a concentration of 50 cells $\mathrm{ul}^{-1}$ of final culture volume (Lutz et al., 1982).

For experiments subsamples of larvae were collected from the culture by siphoning through a 'Nitex' nylon mesh and subsequently washing the larvae into a small volume of filtered sea water. The larvae were counted and a known number transferred to the experimental chamber. At the end of the experiment a subsample of larvae (ca. 1000 individuals) was removed and fixed in a buffered formalin, and measured to length (the longest dimension) on a Leitz compound microscope fitted with an ocular micrometer.

The experimental apparatus for examining response to pressure stimuli is illustrated in Fig. 1. With this apparatus the diameter, $\mathrm{D}$, of the helical swimming pattern; the vertical distance travelled per rotation, $\mathrm{H}$, and the vertical distance travelled, $K$, in a unit time interval, $T$, could be recorded. From $D, H, K$ and $T$ the following could be calculated:

$$
\begin{aligned}
& \text { vertical velocity }=K / T \\
& \text { absolute velocity }=K \frac{\sqrt{H^{2}+(\pi D)^{2}}}{H T} \\
& \text { pitch of helix }=\sigma \cdot \tan \sigma=H / \pi D
\end{aligned}
$$

Prior to an experiment larvae were allowed to acclimate to the experimental chamber for a period of $2 \mathrm{~h}$. The use of compressed nitrogen gas as a pressure regulator and an experimental chamber which was closed during acclimation allowed the maintenance of the control condition at 1 bar absolute pressure (where 1 bar $=1$ atmosphere $\simeq 10 \mathrm{~m}$ of water) rather than ambient pressure. All measurements are given in absolute pressure. All experiments were carried out at $12{ }^{\circ} \mathrm{C}$ in $0.22 \mu \mathrm{m}$ filtered sea water supplemented with

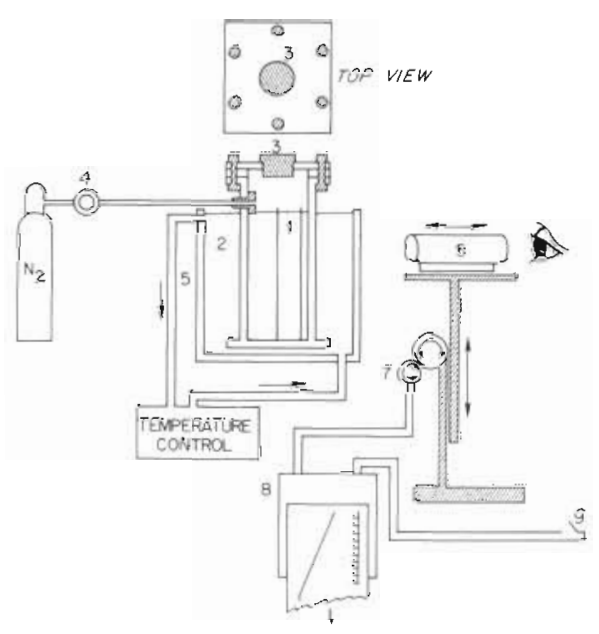

Fig. 1. Apparatus (not to scale) for measuring response of Arctica islandica larvae to pressure. Larvae were maintained in a glass tube $(1.5 \mathrm{~cm}$ diam. $\times 17 \mathrm{~cm}$ high, labelled 1$)$ closed at one end and held in a $20 \mathrm{~cm}$ high $\times 5 \mathrm{~cm}$ wide $\times 4 \mathrm{~cm}$ deep Plexiglas pressure chamber (2). Access to the chamber was through a port (3) in the top of the chamber. The top was held in place by 6 stainless steel bolts and sealed by a neoprene rubber gasket. Pressure in the chamber was controlled via a 2 stage pressure regulator (4) attached to a cylinder of nitrogen gas. The pressure chamber was immersed in a Plexiglas water jacket (5) and maintained at $12^{\circ} \mathrm{C}$ by a recirculating water bath. Larval swimming behaviour was observed using a dissecting microscope (6) mounted on a dual rack system that allowed movement in both the vertical and horizontal planes. A 10 tum potentiometer (7) was connected to the vertical adjustment handle. Output from the potentiometer was connected to one channel of a chart recorder (8). Calibration of potentiometer output against vertical displacement of the microscope in conjunction with a fixed rate of chart paper speed allowed the estimation of rate of vertical velocity of selected larvae if the latter were followed and maintained in the cross hairs of the microscope eyepiece. With the microscope on its lowest power the width of the tube (1) could be seen and the depth of the tube (1) was equal to the depth of field of the microscope. The diameter of the helical swimming pattern was estimated on an ocular grid in the microscope. An event marker (9) was activated to give a record on the recorder (8) on completion of each rotation 
Isochrysis galbana to a final concentration of 50 cells $\mu l^{-1}$. To assess the influence of an increase or decrease in absolute pressure on net larval movement (up or down) the microscope was focussed on a point midway between the top and bottom of the tube containing the larvae. The pressure was sequentially increased and decreased as illustrated in Fig. 2A. The number of

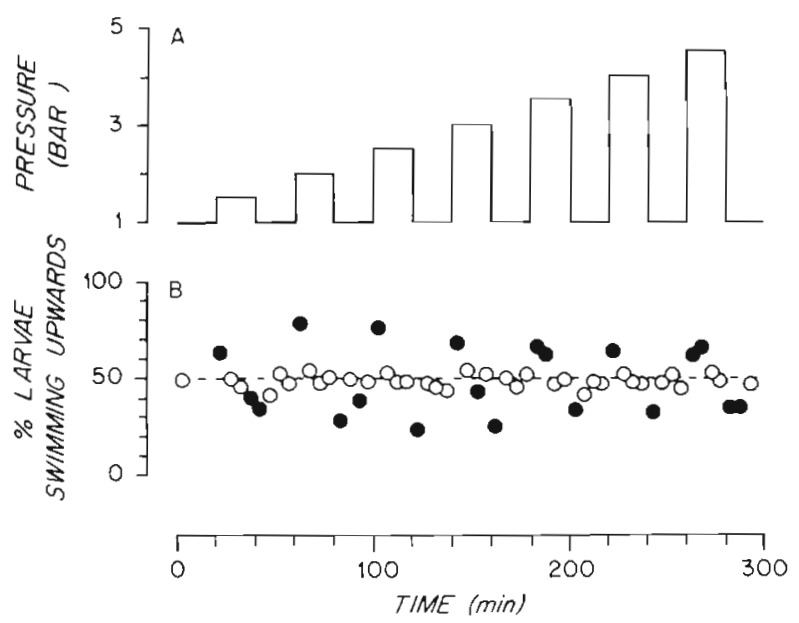

Fig. 2. Arctica islandica. Swimming response of $160 \mu \mathrm{m}$ long larvae to stepwise increases or decreases in pressure. (A) Temporal changes in pressure; (B) larval swimming response by $5 \mathrm{~min}$ intervals. Closed circles at various pressures indicate a significant $(5 \%$ level) difference from response at equilibrium of one bar; open circles: no net upward or downward movement

larvae ascending and descending past a horizontal line on the ocular grid, and extending across the complete width of the tube was recorded for 4 consecutive intervals of $5 \mathrm{~min}$ following each change in pressure. On completion of a $20 \mathrm{~min}$ period at one pressure, the next pressure change was effected and the counting process repeated. During a typical $5 \mathrm{~min}$ counting period between 50 and 250 moving larvae would be counted. An initial experiment indicated that within $20 \mathrm{~min}$ following a single, stepwise pressure-change the net larval movement in either the upward or downward movement through the plane of observation had ceased. The 20 min time base illustrated in Fig. 2A was, therefore, subsequently used.

Four experiments were performed to count the numbers of larvae swimming upward and sinking passively at different pressures. The first experiment used the pressure regime in Fig. $2 \mathrm{~A}$ for $160 \mu \mathrm{m}$ ( $\pm 13 \mu \mathrm{m}$ s.d., $\mathrm{n}=30$ ) long larvae. The remaining 3 experiments used the pressure regime of Fig. 3A for $160 \mu \mathrm{m}, 183 \mu \mathrm{m}$ $( \pm 11 \mu \mathrm{m}$ s.d., $\mathrm{n}=30)$ and $196 \mu \mathrm{m}( \pm 13 \mu \mathrm{m}$ s.d. $\mathrm{n}=30$ ) long larvae respectively and counted only during the first $5 \mathrm{~min}$ following a pressure change. For each 5 min counting period the percentage of bivalves swimming upwards was calculated. This value was compared by chi-squared analysis to the null hypothesis value of $50 \%$ which describes no net upward or downward motion.

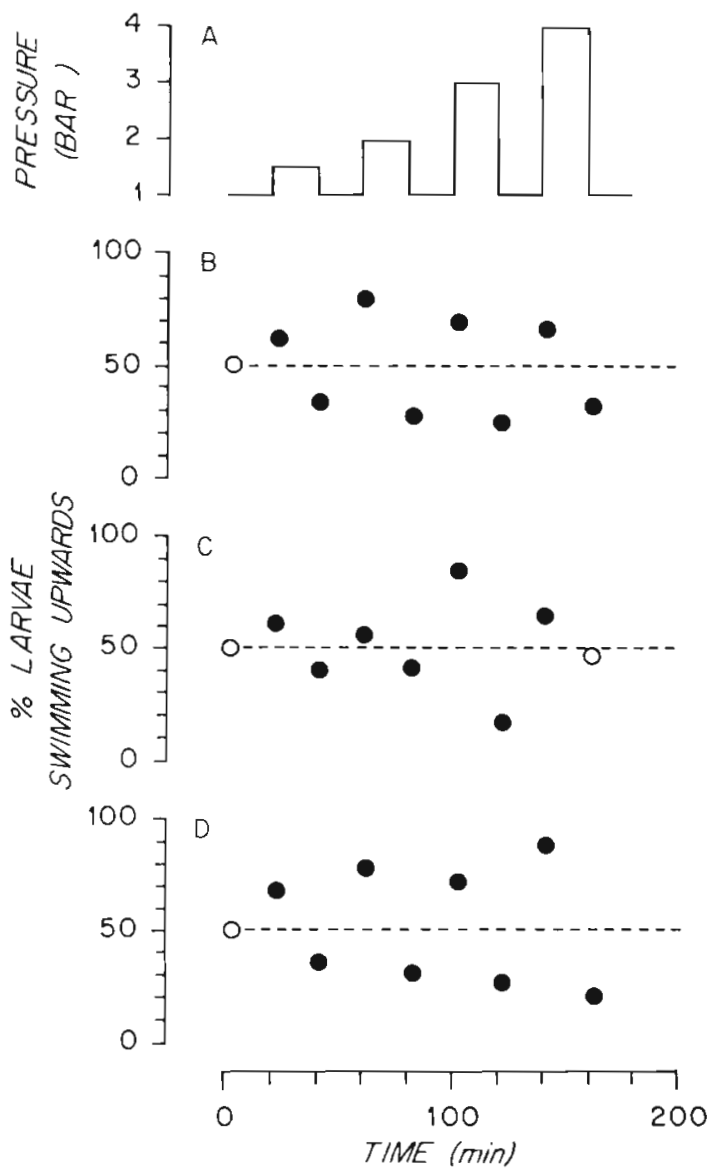

Fig. 3. Arctica islandica. Swimming response of larvae to stepwise increases and decreases in pressure. (A) Temporal changes in pressure. (B) Swimming response for $160 \mu \mathrm{m}$ long larvae; data are for numbers of larvae observed during first $5 \mathrm{~min}$ following change in pressure. Closed circles: net movement significantly different from that at equilibrium at 1 bar. (C) As for (B) but larvae are $183 \mu \mathrm{m}$ long. D) As for (B) but larvae are $196 \mu \mathrm{m}$ long

In a second series of 3 experiments the values of $D$, $\mathrm{H}, \mathrm{K}$ and $\mathrm{T}$ were recorded for Arctica islandica larvae at $170 \mu \mathrm{m}( \pm 10 \mu \mathrm{m}$ s.d., $\mathrm{n}=30), 196 \mu \mathrm{m}$ ( $\pm 13 \mu \mathrm{m}$ s.d., $\mathrm{n}=30)$, and $202 \mu \mathrm{m}( \pm 10 \mu \mathrm{m}$ s.d., $\mathrm{n}=30)$ length respectively. Measurements were made at 1 bar and subsequently at 4 bar. In the case of $202 \mu \mathrm{m}$ larvae an intermediate series of readings was made at 2.5 bar. Larvae were maintained at the experimental pressure for $2 \mathrm{~h}$ before recordings were made. Mean and standard error for swimming components were calculated and comparisons made using a 2 tailed t-test. Some observations were also made of trochophore larvae in the pressure chamber. 
A final series of experiments was performed to examine whether Arctica islandica larvae exhibited temperature preference. At a water change larvae were removed and transferred to a glass $250 \mathrm{ml}$ measuring cylinder containing freshly filtered sea water enriched to 50 cells $\mu^{-1}$ with Isochrysis galbana. The base of the cylinder was immersed in an ice bath while the tip of a $30 \mathrm{~W}$ immersion heater, thermostatically regulated at a maximum temperature of $30^{\circ} \mathrm{C}$, was immersed in the top $5 \mathrm{~cm}$ of the water. The contents of the cylinder were left to equilibrate for $1 \mathrm{~h}$. Additions of ice to the lower bath were made as neces-

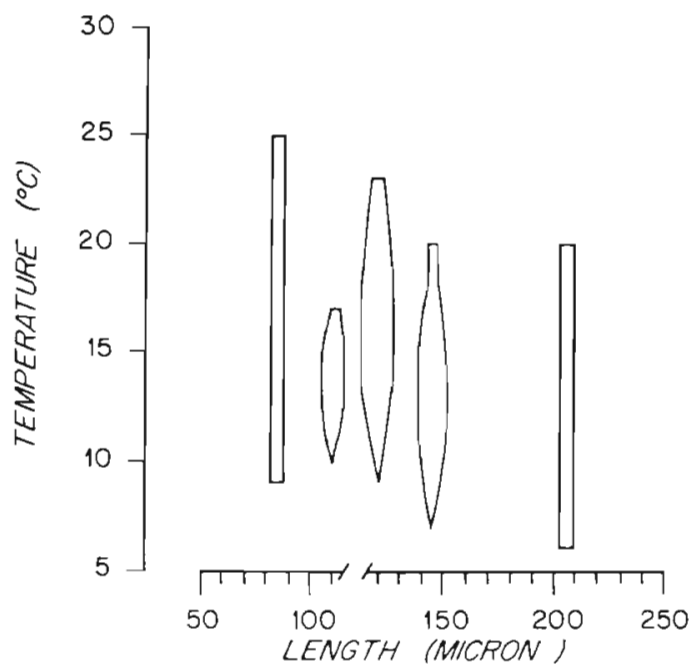

Fig. 4. Arctica islandica. Equilibrium distribution of trochophore and veliger larvae of varying sizes in a vertical thermal gradient. Width of bar proportionate to numbers of larvae

sary. An initial experiment performed without larvae demonstrated the formation of a stable thermal gradient from ca. $2{ }^{\circ} \mathrm{C}$ at the base of the cylinder to ca. $30^{\circ} \mathrm{C}$ at the top of the cylinder in less than 30 min. After the $1 \mathrm{~h}$ equilibration period the numbers of larvae in sequential sections, each ca. $3 \mathrm{~cm}$ deep, were counted from the top to the bottom of the cylinder. The temperature gradient was subsequently recorded by lowering a large-bulb, mercury-in-glass thermometer down the cylinder and taking readings at similar intervals. A plot was made of numbers of larvae versus temperature per section (Fig. 4).

Both pressure and thermal response experiments were performed in dim white light, room illumination and a single point-source white light to illuminate the field of view of the microscope. An initial experiment was performed to investigate any possible phototactic response. Shelled veliger larvae of Arctica islandica were held in the apparatus (Fig. 1) for a $2 \mathrm{~h}$ acclimation period with a single point-source white light held directly above the pressure chamber in an otherwise dark room. A uniform distribution of larvae was observed throughout the depth of the chamber. The lack of aggregation at either the surface or base of the chamber was interpreted as a lack of phototactic response by $A$. islandica veliger larvae. The experimental light regime employed for pressure and thermal response experiments was, therefore, deemed appropriate.

\section{RESULTS}

Larvae of $160 \mu \mathrm{m}$ length exhibit a net upward swimming movement during the 5 min period immediately following an increase in pressure and a net sinking during a corresponding period following a decrease in pressure to 1 bar (Figs. 2B, 3B). This behaviour was consistent throughout the complete range of pressure changes examined. Infrequently a significant net movement was recorded in the same direction as that immediately following the pressure change in the period extending from 5 to 15 min after a pressure change.

In all but one instance a similar pattern of net movement during the 5 min interval immediately following a change in pressure was also recorded for $183 \mu \mathrm{m}$ and $196 \mu$ long larvae (Fig. 3C, D). These data suggest that, in the length range 160 to $196 \mu \mathrm{m}$, swimming activity of Arctica islandica larvae is stimulated by an increase in pressure. This is manifest in laboratory experiments by upward movement due to apparent negative geotaxis.

The response of the components of swimming activity in Arctica islandica larvae to increased pressure are not consistent throughout larval development. The mean absolute swimming velocity of a $170 \mu \mathrm{m}$ long $A$. islandica larvae is approximately twice its vertical velocity at 1 bar (Table 1). On increasing pressure the diameter of the helix and the gain in height per rotation increases; however, neither vertical or absolute velocity differ significantly from values at 1 bar (Table 1). A $196 \mu \mathrm{m}$ long larva at 1 bar maintains a vertical velocity similar to a $170 \mu \mathrm{m}$ long larva, but does so with a significantly lower absolute velocity combined with a smaller diameter helical pattern (Table 1). Larvae of $196 \mu \mathrm{m}$ length respond to increased pressure by increasing their gain in height per rotation and their vertical velocity. Larvae of $202 \mu \mathrm{m}$ length at 1 bar, like $196 \mu \mathrm{m}$ long larvae, have a smaller diameter of helix than $170 \mu \mathrm{m}$ long larvae. Unlike smaller larvae, $202 \mu \mathrm{m}$ long larvae do not exhibit significant changes in any of the components of swimming under increased pressure.

Trochophores, unlike the shelled larval stages, were 
Table 1. Arctica islandica. Components of swimming behaviour in larvae. All values are mean \pm standard error. Significant difference from accompanying value at 1 bar indicated thus: $a ; P<0.05$; $b ; P<0.01$. Significant difference (P $<0.01$ ) from corresponding value recorded for $170 \mu \mathrm{m}$ larvae indicated by $\mathrm{c}$

\begin{tabular}{|c|c|c|c|c|c|c|c|}
\hline $\begin{array}{c}\text { Mean } \\
\text { length } \\
(\mu m)\end{array}$ & $\begin{array}{c}\text { Pressure } \\
\text { (bar) }\end{array}$ & $\mathrm{n}$ & $\begin{array}{l}\text { Vertical } \\
\text { velocity } \\
\left(\mathrm{mm} \mathrm{s}^{-1}\right)\end{array}$ & $\begin{array}{l}\text { Absolute } \\
\text { velocity } \\
\text { (mnn s } \mathrm{s}^{-1} \text { ) }\end{array}$ & $\tan \sigma$ & $\begin{array}{l}\text { Height per } \\
\text { rotation } \\
\text { (mm) }\end{array}$ & $\begin{array}{c}\text { Diameter } \\
\text { helix } \\
\text { (mm) }\end{array}$ \\
\hline \multirow[t]{2}{*}{170} & 1 & 31 & $.37 \pm .05$ & $.76 \pm .04$ & $1.0 \pm 0.3$ & $1.4 \pm 0.1$ & $.90 \pm .06$ \\
\hline & 4 & 32 & $.49 \pm .05$ & $.68 \pm .05$ & $2.0 \pm 0.4^{\mathrm{a}}$ & $1.9 \pm 0.2^{\mathrm{a}}$ & $.51 \pm .05^{b}$ \\
\hline \multirow[t]{2}{*}{196} & 1 & 30 & $.32 \pm .03$ & $.53 \pm .03^{\mathrm{c}}$ & $1.1 \pm 0.2$ & $1.4 \pm 0.1$ & $.59 \pm .06^{c}$ \\
\hline & 4 & 31 & $.52 \pm .05^{b}$ & $.75 \pm .05$ & $1.5 \pm 0.2$ & $1.9 \pm 0.1^{b}$ & $.57 \pm .05$ \\
\hline \multirow[t]{3}{*}{202} & 1 & 20 & $.28 \pm .04$ & $.48 \pm .05$ & $1.1 \pm 0.2$ & $1.4 \pm 0.2$ & $.51 \pm .05^{c}$ \\
\hline & 2.5 & 20 & $.20 \pm .03$ & $.44 \pm .05$ & $0.7 \pm 0.1$ & $1.0 \pm 0.1$ & $.52 \pm .05$ \\
\hline & 4 & 20 & $.23 \pm .03$ & $.53 \pm .05$ & $0.6 \pm 0.1$ & $1.0 \pm 0.1$ & $.64 \pm .06$ \\
\hline
\end{tabular}

observed to swim continually and, after a $45 \mathrm{~min}$ equilibration period at 1 bar at $12^{\circ} \mathrm{C}$, exhibited aggregation in the surface layer of the containing tube. The trochophores exhibited only small vertical excursions (1 to $2 \mathrm{~cm}$ ) from the water surface. This pattern of swimming and aggregation was maintained throughout stepwise pressure increments of 0.5 bar to 3 bar in both light and dark and was not influenced by pointsource illumination from below or the side in a darkened room. The swimming behaviour of the trochophores appears to be negatively geotactic and devoid of a phototactic response in a constant temperature environment.

In an intense thermal gradient, however, the marked surface aggregation is not evident. Trochophores swim actively but without any apparent preferential temperature in the range 9 to $25^{\circ} \mathrm{C}$ but do not exceed the latter temperature (Fig. 4). Movement away from the temperature maximum involves reduction rather than cessation of swimming. Arctica islandica veliger larvae of $110 \mu \mathrm{m}( \pm 6 \mu \mathrm{m}$ s.d., $\mathrm{n}=30$ ) length swim in a temperature range between 10 and $17^{\circ} \mathrm{C}$ with a preference for the 12 to $15^{\circ} \mathrm{C}$ range (Fig. 4). At a length of $120 \mu \mathrm{m}( \pm 11 \mu \mathrm{m}$ s.d., $\mathrm{n}=30$ ) the active range extends from 9 to $23^{\circ} \mathrm{C}$ with a preference range of 14 to $17^{\circ} \mathrm{C}$. With increasing size through $145 \mu \mathrm{m}$ ( $\pm 11 \mu \mathrm{m}$ s.d., $\mathrm{n}=30)$ to $204 \mu \mathrm{m}( \pm 14 \mu \mathrm{m}$ s.d., $\mathrm{n}=30)$ the upper temperature limit of swimming activity is sharply demarcated at $20^{\circ} \mathrm{C}$ while the lower temperature limit extends to $6{ }^{\circ} \mathrm{C}$. Within this range no temperature preference is obvious for $204 \mu \mathrm{m}$ larvae. Although the temperature maximum was clearly defined in all larvae the lower limit of activity required careful observation because descending larvae often sank either trailing their velum or with closed valves. On reaching the lower temperature limit of activity animals with closed valves often failed to recommence swimming and sank to the base of the cylinder where, at ca. $2^{\circ} \mathrm{C}$, they remained closed until the completion of the experiment. There was therefore a small but continuous loss of moving larvae to the bottom of the cylinder throughout the observation period.

\section{DISCUSSION}

Arctica islandica veliger larvae exhibit alternating periods of sinking and swimming in a vertically oriented helical path in the manner previously described for Mytilus edulis (Bayne, 1964), Ostrea edulis (Cragg and Gruffydd, 1975) and Pecten maximus (Cragg, 1980). During the sinking phase the velum is often trailed rather than retracted as for $O$. edulis and $P$. maximus. Mileikovsky (1973) has reviewed the speed of active vertical movement of pelagic larvae of marine benthic invertebrates; most fall in the range 0.67 to $2.00 \mathrm{~mm} \mathrm{~s}^{-1}$. Cragg (1980) reviews data for bivalve larvae. Published values include 1.17 to $1.33 \mathrm{~mm} \mathrm{~s}^{-1}$ for Mercenaria mercenaria (Turner and George, 1955), $7.7 \mathrm{~mm} \mathrm{~s}^{-1}$ for Teredo bartschi" (Isham and Tierney, 1953), $1.1 \mathrm{~mm} \mathrm{~s}^{-1}$ for $M$. edulis (Konstantinova, 1966), 0.75 to $10 \mathrm{~mm} \mathrm{~s}^{-1}$ for Crassostrea virginica (Wood and Hargis, 1971; and Hidu and Haskin, 1978), $1.23 \mathrm{~mm} \mathrm{~s}^{-1}$ for $O$, edulis (Cragg and Gruffydd, 1975) and 0.17 to $0.46 \mathrm{~mm} \mathrm{~s}^{-1}$ for $P$. maximus (Cragg, 1980). The values for veliger larvae of $A$. islandica (Table 1 ) are clearly near the bottom of these ranges being comparable only with those of $P$. maximus; however, the experimental temperature employed during the pressure studies in the present work was generally lower than those previously used with the exception of Cragg (1980) where P. maximus larval swimming was observed at $14^{\circ} \mathrm{C}$. The larvae of A. islandica have a similar helical pitch but a smaller diameter to their helical swimming pattern than $O$. edulis (Cragg and Gruffydd, 1975: Table II). The ten-

\footnotetext{
- Although described as Teredo (Lyrodus) pedicellata by Isham and Tierney (1953) this species was later shown to be Teredo bartschi by Turner and Johnson (1971)
} 
dency to increase vertical swimming speed under pressure by changing the helical swimming pattern to one of steeper, narrower spirals has been noted previously by Bayne (1963) for $M$. edulis and Cragg and Gruffydd (1975) for $O$. edulis. This pattern is also noted with $170 \mu \mathrm{m}$ A. islandica larvae in our study.

The threshold change in pressure required to stimulate a significant deviation from equilibrium swimming pattern has been recorded for the veligers of Mercenaria mercenaria (<0.1 bar, Haskin, 1964) and Ostrea edulis ( 0.1 to 0.2 bar depending on age; Cragg and Gruffydd, 1975). Fig. 2 and 3 indicate that for Arctica islandica such a threshold is less than 0.5 bar, comparable to the veligers of Mytilus edulis (Bayne, 1963) and considerably more sensitive than the veligers of Pecten maximus (1.0 to 1.2 bar depending upon age; Cragg, 1980). Cragg (1980) suggests that selection pressures favour a more sensitive depth regulatory mechanism in littoral species than in sublittoral species. In the northerly portion of its geographic range (reviewed by Franz and Merrill, 1980; Lutz et al., 1982, and Mann, 1982) A. islandica can indeed be found in shallow, sublittoral depths. In $A$. islandica larvae the periods of passive sinking provide a gradual increase in pressure which elicit a subsequent negatively geotactic swimming response. The combination of threshold pressure change to elicit swimming of less than 0.5 bar and a net upward swimming movement in response to all increases in pressure above 1 bar suggests an aggregation of $A$. islandica veligers in shallow depths in natural waters. This response may, however, be modified by thermal stratification, where the absolute temperature in shallow water exceeds the preferred temperature for larval activity. In such a case depth regulation will be effected through temperature stimuli, which discourage upward swimming, and pressure stimuli, which encourage upward swimming, acting in opposition. It is relevant to ask what are the implications of this model on seasonal depth distribution of the larvae of $A$. islandica in the Middle Atlantic Bight.

Fig. 5A (after Mann, 1982: Fig. 1) shows depth versus time isotherms of water temperature on the Southern New England Shelf. Fig. 5B illustrates the percentage of adult Arctica islandica in a partly spawned condition which are actively contributing to the larval numbers in the overlaying waters. Spawning of $A$. islandica begins in late May of early June (see also Jones, 1982) with rising bottom temperatures. Our study suggests that trochophores and veliger larvae resulting from these spawnings will swim upwards (Fig. 2 to 4). Bottom temperatures continue to rise through the summer and remain above $6{ }^{\circ} \mathrm{C}$, the minimum preferred temperature (Fig. 4), until the following December. The growth rate of $A$. islandica

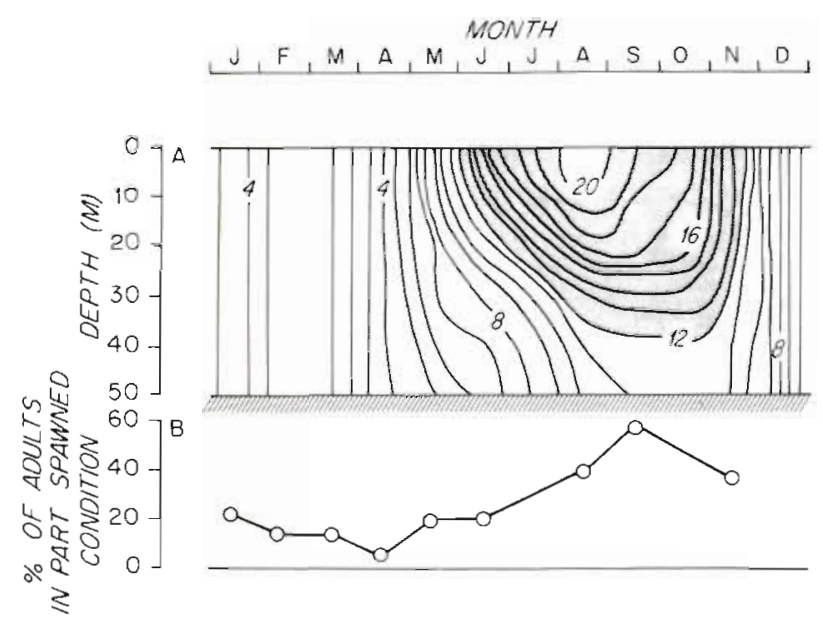

Fig. 5. (A) Depth versus time isotherm plot of water temperature at a station in $50 \mathrm{~m}$ depth of water on the southern New England Shelf (replotted from Mann, 1982: Fig. 1, Station 1). Shaded area represents predicted depth range of occurrence versus time of Arctica islandica larvae. (B) Percentage of adult $A$. islandica in part spawned condition versus time (replotted from Mann, 1982)

larvae in culture at $9{ }^{\circ} \mathrm{C}$ is much slower than at $13{ }^{\circ} \mathrm{C}$ under otherwise identical conditions (Lutz et al., 1982), especially so during the initial period of growth to $130 \mu \mathrm{m}$ length $\left(8 \mathrm{~d}\right.$ at $13^{\circ} \mathrm{C}$ versus $18 \mathrm{~d}$ at $9^{\circ} \mathrm{C}$ ). Landers (1976) found that fertilization of $A$. islandica eggs is achieved between 10 and $20^{\circ} \mathrm{C}$, but developing larvae only survive to veligers at 10 to $15^{\circ} \mathrm{C}$, and to metamorphosis at 10 to $12{ }^{\circ} \mathrm{C}$. Lutz et al. (1982) maintained $A$. islandica larvae through metamorphosis at 9 to $13^{\circ} \mathrm{C}$. As the spawning season progresses and surface temperatures rise above $20^{\circ} \mathrm{C}$, behavioural responses of larvae promote movement to greater depth. Consequently the larvae maintain a preferred temperature for development (Fig. 4 and 5). Pressure stimulated response (Fig. 2 and 3 ) is moderated by a combination of maximum and preferred thermal ranges (Fig. 4). The maximum temperature at which swimming is observed (Fig. 4) is not conducive to high survival and growth rate (Landers, 1976). An aggregation of developing $A$. islandica laryae in or below the seasonal thermocline is therefore expected throughout the summer months in the Middle Atlantic Bight.

The shaded region of Fig. 5 shows a depth range and time where the model predicts that the larvae of Arctica islandica should occur. At the extremes of the spawning season the limits are defined by the $9^{\circ} \mathrm{C}$ isotherm and the $5 \mathrm{~m}$ isobath. It is predicted that between June and November larvae will not be found below the $12^{\circ} \mathrm{C}$ isotherm (Fig. 4) with the possible exception of settling pediveligers (not examined here). It is also predicted that the pressure response promotes upward movement by larvae from the $12{ }^{\circ} \mathrm{C}$ into the 
area of $>14{ }^{\circ} \mathrm{C}$, a preferred temperature for larvae in the length range 110 to $145 \mu \mathrm{m}$ and at the median of the swimming range of larger larvae (Fig. 4). The shallow limit will be determined by the preferred swimming temperature (Fig. 4), pressure response and longterm survival at higher temperatures. This shallow limit is probably set by the $20^{\circ} \mathrm{C}$ isotherm and may, therefore, 'sink' during the summer. The actual shallow and deep limits of larval distribution with season is unknown. It is not until the thermocline degrades and allows vertical mixing of the water column in September or October that the individual pressure and temperature stimulated swimming responses complement one another and support the prediction of an aggregation of $A$. islandica larvae in the surface waters. Spawning of adult $A$. islandica continues into the fall. Trochophore and veliger larvae from these spawnings will continue to experience surface directed stimuli until water temperatures decrease to a level below which continued development will not occur.

If the stratification of larvae suggested in Fig. 5 were to occur, how would it influence the horizontal dispersion process? If larvae survive to metamorphosis while restricted to a depth below the thermocline then their passive dispersal will be influenced by Ekman flow and the southwesterly direction of flow of 'Cold Pool' water (Bumpus, 1965; Harrison et al., 1967; Scheltema, 1975; Beardsley and Boicourt, 1981; the original concept of this pool of water being static, as suggested by Ketchum and Corwin, 1964, is incorrect). Dispersal of larvae entrained in the thermocline will be dominated by turbulent flow in this discontinuity. Finally, dispersal in the surface layers can be influenced by a combination of general southwesterly flow (Bumpus and Lauzier, 1965; Bumpus, 1973; Beardsley and Boicourt, 1981) and local wind forcing, the latter often resulting in reversal of current direction (Bumpus, 1969).

Acknowledgements. This work was supported by US Department of Commerce, NOAA, Sea Grant under Grant Number NA80-AA-D-00077 and by a Summer Student Fellowship (to C. C. Wolf) from Woods Hole Oceanographic Institution. The authors are indebted to Glenn Sasaki for construction of the pressure chamber, Captain Richard Ferrara for collection of adult Arctica islandica, Dr. R. S. Scheltema and Dr. S. D. Sulkin for much useful discussion, and Ms. Elaine M. Lynch for typing the manuscript.

\section{LTTERATURE CITED}

Bayne, B. L. (1963). Responses of Mytilus edulis larvae to increases in hydrostatic pressure. Nature, Lond. 198: 406-407

Bayne, B. L. (1964). The responses of the larvae of Mytilus edulis L. to light and to gravity. Oikos 15: 162-174
Beardsley, R. C., Boicourt, W. C. (1981). On estuarine and Continental Shelf circulation in the Middle Atlantic Bight. In: Warren, B. A., Wunsch C. S. (ed.) Evolution in physical oceanography: essays on the 60th Birthday of Henry Stommel. MIT Press, Cambridge, Ma., USA, p. 198-233

Bigelow, H. B. (1933). Studies of the waters on the continental shelf, Cape Cod to Chesapeake Bay, I, the cycle of temperature. Phys. Oceanogr. Meteorol. 2: 1-135

Bumpus, D. F. (1965). Residual drift along the bottom on the continental shelf in the middle Atlantic Bight area. Limnol. Oceanogr. 10 (Suppl.): R50-53

Bumpus, D. F. (1969). Reversals in the surface drift in the middle Atlantic Bight area. Deep Sea Res. 16; 17-23

Bumpus, D. F. (1973). A description of the circulation on the continental shelf of the east coast of the United States. Prog. Oceanogr. 6: 111-157

Bumpus, D. F., Lauzier, L. M. (1965). Surface circulation on the continental shelf off eastern North America between Newfoundland and Florida. In: Webster, W. (ed.) Serial atlas of the marine environment. Am. Geogr. Soc. Folio 7. $4 \mathrm{p} ., 8 \mathrm{pl}$.

Carriker, M. R. (1961). Interrelation of functional morphology, behaviour and autecology in early stages of the bivalve Mercenaria mercenaria. J. Elisha Mitchell scient. Soc. 177: $168-242$

Cragg, S. M. (1980). Swimming behaviour of the larvae of Pecten maximus (L.) (Bivalvia). J. mar. biol. Ass. U.K. 60: 551-564

Cragg, S. M., Gruffydd, Ll. D. (1975). The swimming behaviour and the pressure responses of the veliconcha larvae of Ostrea edulis (L.). In: H. Barnes (ed.) Proceedings of the Ninth European Marine Biology Symposium, Oban, Scotland. 1974. Aberdeen University Press, Aberdeen, p. $43-57$

Franz, D. R., Merrill, A. S. (1980). Molluscan distribution patterns on the continental shelf of the Middle Atlantic Bight (Northwest Atlantic). Malacologia 19(2): 209-225

Harrison, W., Norcross, J. J., Pore, N. A., Stanley, E. M. (1967). Circulation of shelf waters off Chesapeake Bight - surface and bottom drift of continental shelf waters between Cape Henlopen, Delaware, and Cape Hatteras, North Carolina. June 1963 - December 1964. U.S. ESSA Prof. Pap. 3: 1-82

Haskin, H. H. (1964). The distribution of oyster larvae. In: Marshall, N., Jeffries, H. P., Napora, T. A., Sieburth, J. M. (ed.) Symposium on experimental marine ecology, Graduate School of Oceanography, University of Rhode Island. Occ. Publ. 2: 76-80

Hidu, H., Haskin, H. H. (1978). Swimming speeds of oyster larvae Crassostrea virginica in different salinities and temperatures. Estuaries 1: 252-255

Isham, L. B., Tierney, J. Q. (1953). Some aspects of the larval development and metamorphosis of Teredo (Lyrodus) pedicellata de Quatrefages. Bull. mar. Sci. Gulf Carib. 2: $574-589$

Jones, D. S. (1982). Reproductive cycles of the Atlantic surf clam Spisula solidissima and the ocean quahog Arctica islandica off New Jersey. J. Shellfish Res. 1(1): 23-32

Ketchum, B. H., Corwin, N. (1964). The persistence of 'winter' water on the continental shelf south of Long Island. Limnol. Oceanogr 9: 467-475

Konstantinova, M. I. (1966). Characteristics of the motion of pelagic larvae of marine invertebrates. Doklady (Proceedings) Academy of Sciences of the U.S.S.R. (Biological Sciences) 170: 753-756

Landers, W. S. (1976). Reproduction and early development of the ocean quahog, Arctica islandica, in the laboratory. Nautilus 90: 88-92 
Loosanoff, V. L. (1953). Reproductive cycles in Cyprina islandica. Biol. Bull. mar. biol. Lab, Woods Hole 104: 146-155

Lutz, R. A., Mann, R., Goodsall, J. G., Castagna, M. (1982) Larval and early post larval development of the ocean quahog Arctica islandica. J. mar. biol. Ass. U.K. 62: $745-769$

Mann, R. (1982). The seasonal cycle of gonadal development in Arctica islandica from the Southem New England Shelf. Fish. Bull. 80 (2): 315-326

Merrill, A. S., Ropes, J. W. (1969). The general distribution of the surf clam and ocean quahog. Proc. natn. Shellfish. Ass. 59: $40-45$

Mileikovsky, S. A. (1973). Speed of active movement of pelagic larvae of marine bottom invertebrates and their ability to regulate their vertical position. Mar. Biol. 23: $11-17$

Scheltema, R. S. (1975). Relationship of larval dispersal, gene flow and natural selection to geographic variation of benthic invertebrates in estuaries and along coastal reg- ions. In: Cronin, L. E. (ed.) Estuarine research, Vol. 1: Chemistry, biology and the estuarine system. Academic Press, London, p. 372-391

Turner, H. J., George, C. J. (1955). Some aspects of the behaviour of the quahaug, Venus mercenaria, during the early stages. In: Eight report of investigations of the shellfisheries of Massachusetts. Department of Natural Resources, Division of Marine Fisheries, Commonwealth of Massachusetts, p. 5-14

Turner, R. D., Johnson, A. C. (1971). Biology of marine wood boring molluscs. In: Jones, E. B. G., Eltringham, S. K. (ed.) Marine borers, fungi and fouling organisms of wood. Organization for Economic Co-operation and Development, Paris, p. 259-301

Wood, L., Hargis, W. J. (1971). Transport of bivalve larvae in a tidal estuary. In: Crisp, D. J. (ed.) Proceedings of the Fourth European Marine Biology Symposium, Bangor, 1969. Cambridge University Press, Cambridge, p. 29-44

This paper was presented by Dr. R. S. Scheltema; it was accepted for printing on May 14, 1983 